\title{
Carotenoid Assessments and Antioxidant Activities from Flower Petals
}

\author{
Khakhanang Ratananikom ${ }^{1 *}$, Nipa Nasinporm ${ }^{2}$, Tanitpan Pongjongmit ${ }^{2}$ \\ ${ }^{1}$ Faculty of Science and Health Technology, Kalasin University, Kalasin, Thailand \\ ${ }^{2}$ Faculty of Agricultural Technology, Kalasin University, Kalasin, Thailand
}

\section{ARTICLE INFO}

Article history:

Received September 1, 2021

Received in revised form September 14, 2021

Accepted October 11, 2021

\section{KEYWORDS:}

flower,

carotenoids,

antioxidant

\begin{abstract}
The objectives of this study were to evaluate carotenoid pigment profile and the antioxidant activity from 14 commonly grown flowers in Thailand. The result found that orange marigold showed the highest total carotenoid content at as $2,209 \pm 75.58 \mu \mathrm{g} / \mathrm{g}$, followed by deep yellow chrysanthemum at $551.27 \pm 47.72 \mu \mathrm{g} / \mathrm{g}$ $(\mathbf{P}<0.01)$. The next lower total carotenoid content group was found in yellow silk cotton, yellow trumpetbush, yellow marigold and yellow golden shower with total carotenoid content of $447.42 \pm 27.56,429.46 \pm 28.34,409.85 \pm 34.58$ and $363.88 \pm 12.74 \mu \mathrm{g} / \mathrm{g}$, respectively. The highest antioxidant activities against DPPH and ABTS radicles were found from orange marigold, which were $32.34 \pm 2.16$ and $\mathbf{5 0 . 0 8} \pm \mathbf{0 . 8 7} \%$, respectively. Deep yellow chrysanthemum, yellow silk cotton, yellow trumpetbush, yellow marigold and yellow golden shower also showed significantly higher antioxidant activities than other flowers $(P<0.01)$. Total carotenoid contents well correlated with antioxidant activities against DPPH and ABTS radicals ( $r=$ 0.6924 and $r=0.8270$, respectively) at $P<0.01$. TLC result elucidated that orange marigold, yellow silk cotton and yellow golden shower were a good source of $\beta$-carotene, while deep yellow chrysanthemum and yellow marigold were a good source of lutein and/or zeaxanthin. The result indicated that flower petals would be useful as natural carotenoid source and provide antioxidants for food industry.
\end{abstract}

\section{Introduction}

Carotenoids are pigment, which are commonly found in nature. They exhibit yellow, orange and red color. Their structures consist of 8 isoprene units, connected by covalent bonds (Britton etal.2004). They are categorized into 2 main groups, according to their structures: carotenes and xanthophylls. Carotenes are hydrocarbon, including $\beta$-carotene, $\alpha$-carotene and lycopene on the other hand Xanthophylls contain oxygen atoms in their molecules such as lutein, zeaxanthin, astaxanthin and canthaxanthin (Britton et al. 2017). Additionally, to advantage as pigment that distribute yellow, orange and red color, they also play important roles regarding health for humans and animals, such as antioxidant activity, enhancement of immunity, contribution to reproduction, prevention of cancer and lifestyle-related diseases, as well as being vitamin A precursor. Although photosynthetic plants, algae and cyanobacteria can synthesize carotenoids, humans and animals are unable to

\footnotetext{
* Corresponding Author

E-mail Address: khakhanang_r@yahoo.com
}

perform carotenoids synthesis de novo. Carotenoids can be obtained from food and modified through metabolic reactions and subsequently incorporate in some specific organs and tissues, such as egg yolk, skin, legs, beak and feather (Zeb and Murkovic 2010; Maoka 2020). As a result of advantages mentioned above, natural carotenoid sources have been studied such as Chlorella spp., Spirulina spp., carrot, buckthorn berry, linseed, marigold, calendula, basil, and tomato (Karadas et al. 2006; Englmaierová et al. 2014; Skřivan et al. 2015; Kljak et al. 2021; Panaite et al. 2021).

Flowering plants are one of the interesting pigment sources because of a variety of color in flower petals. Therefore, several research laboratories have explored carotenoid profile in flower petals of monocot and eudicot plants by using common 2 techniques, including thin-layer chromatography; TLC and high performance liquid chromatography; HPLC. In general, the majority carotenoids in flower petals are lutein, $\beta$-cryptoxanthin, zeaxanthin, lycopene, and $\beta$-carotene. Interestingly, some flowering plants have modified their carotenoid pathway to synthesis specific carotenoid compositions. Additionally, carotenoid compositions in flower petals are different 
from those found in leaves, resulting to a great diversity of carotenoid composition in flower petals (Ohmiya 2011). Therefore, it could be said that flower petals have a great potential as carotenoid source. However, the study of carotenoids from flower petals is limited in Thailand. Therefore, this research focused on study of carotenoid contents, carotenoid profiles and antioxidant activities from 14 petals of flowers, which have been commonly grown and well adapted to the environment in Thailand. Some of them bloom all year round but some prefer to bloom in specific period. The data obtained from this study would suggest potential carotenoid sources from flower petals that can be used in food and pharmaceutical industry.

\section{Materials and Methods}

\subsection{Sample Preparation}

The fully open 14 flowers were collected and dried by a hot air over at $60^{\circ} \mathrm{C}$ for 24 hours, then grinded into a fine powder and stored in an airtight bag for further study.

\subsection{Total Carotenoids Extraction}

Carotenoids were extracted and total carotenoids contents were analyzed, followed the methods, explained by (Britton et al. 1995a, 1995b) with some modifications. Briefly, $10 \mathrm{ml}$ of acetone and $10 \mathrm{ml}$ of distilled water were used to extract carotenoids from samples, then $20 \mathrm{ml}$ of hexane was added into the mixture. The mixture was gently shaken and set for complete separation. The hexane layer was separated and evaporated by the vacuum evaporator. The absorption at a $450 \mathrm{~nm}$ of the pigment extracts were measured by using petroleum ether as solvent. Total carotenoids contents were calculated using the absorption coefficient. ( $\left.\mathrm{E}^{1 \%, 1 \mathrm{~cm}}\right)$ as 2,500 .

\subsection{Carotenoid Profiles}

Thin layer chromatography analysis was performed on TLC Aluminum oxide 60 F254, neutral (Merck, Germany). The mobile phase consisted of acetone and petroleum ether, in a ratio of 30:70. Chromatogram was developed at room temperature and under dim light on the distance of $5 \mathrm{~cm}$ within 10 min in glass chromatographic chamber, saturated of mobile phase for 30 min. After drying with $\mathrm{N}_{2}$ gas, plates were analyzed with JustTLC software (version 4.6.1, available at http://www.sweday.com/).

\subsection{DPPH Radicle-scavenging Activity}

Analysis of DPPH antioxidant properties was partly modified from the method, explained by BrandWilliams et al. (1995). Fifty microliter of pigment extract and $0.1 \mathrm{mM} \mathrm{2,2} \mathrm{diphenyl-1-picrylhydrazyl}$ radical solution were mixed and incubated at room temperature for 30 minutes in the dark. After that, measured the absorption values at $517 \mathrm{~nm}$. Calculated the percentage of $\mathrm{DPPH}$ antioxidants from the formula.

$$
\text { \% DPPH radical inhibition }=[(\mathrm{A}-\mathrm{B}) / \mathrm{A}] \mathrm{x} 100
$$

When $A$ and $B$ were the absorption values of a DPPH solution without pigment extract and the absorption value of a DPPH solution containing pigment extract, respectively. The measurement was repeated 5 times in each extract type.

\subsection{ABTS Radicle-scavenging Activity}

Analysis of ABTS antioxidant properties was partly modified from the method, explained by Re et al. (1999). Prepared a mixed solution between 2.45 $\mathrm{mM}$ potassium persulfate and $7 \mathrm{mM}$ ABTS in distilled water, stored in dark for 16-18 hours, diluted the solution to obtain absorption values in the range of 0.8-1.0. Fifty microliter of pigment extract and prepared solution were mixed and incubated at room temperature for 30 minutes in the dark. After that, measured the absorption values at $734 \mathrm{~nm}$. Calculated the percentage of ABTS antioxidants from the formula.

\section{$\%$ ABTS radical inhibition $=[(A-B) / A] \times 100$}

When $A$ and $B$ were the absorption values of an ABTS solution without pigment extract and the absorption value of an ABTS solution containing pigment extract, respectively. The measurement was repeated 5 times in each extract type.

\subsection{Statistical Analysis}

Statistix version 8.0 was used for statistical analysis. Data were expressed as mean \pm standard deviation. Measurement data with normal distribution were analyzed using one-way analysis of variance (ANOVA), followed by Least Significantly Difference (LSD) with a significance level of $\alpha=0.05$.

\section{Results}

\subsection{Total Carotenoid Contents and Cntioxidant Activities}

Fourteen flowers were studied in this study, including rose (Rosa hybrida), west Indian jasmine (Ixora chinensis Lamk), golden shower (Cassia fistula L.), orchid tree (Bauhinia purpurea L.), safflower (Carthamus tinctorius L.), impala lily (Adenium obesum (Fosk.) Roem. and Schult.), bastard teak (Butea monosperma), trumpet bush (Tecoma stans), marigold (Tagetes erecta), bougaville (Bougainvillea spp.), globe 
amaranth (Gomphrena globosa L.), chrysanthemum (Chrysanthemum morifolium Ramat), yellow silk cotton (Cochlospermum regium), and butterfly pea (Clitoria ternatea L.). These flowers showed distinct flower petals in term of color as showed in Figure 1.

The highest total carotenoid content was found from orange marigold which reached 2,209.34 \pm 75.58 $\mu \mathrm{g} / \mathrm{g}$ and followed by deep yellow chrysanthemum which reached 551.27 $\pm 47.72 \mu \mathrm{g} / \mathrm{g}$ (Table 1 and Figure $2)$. Other rather high total carotenoid contents were found from yellow silk cotton, yellow trumpetbush, yellow marigold and yellow golden shower with total carotenoids content of $447.42 \pm 27.56$, $429.46 \pm 28.34,409.85 \pm 34.58$, and $363.88 \pm 12.74 \mu \mathrm{g} / \mathrm{g}$, respectively. Moderate low total carotenoid contents, in descending order, were found from yellow chrysanthemum, bougaville with violet, orange and magenta petals as well as west Indian jasmine which were $238.18 \pm 31.86,214.38 \pm 10.35,199.54 \pm 15.26$, $170.35 \pm 9.02$, and $113.86 \pm 6.68 \mu \mathrm{g} / \mathrm{g}$, respectively. Flowers with fairly low total carotenoid contents (lower than $80 \mu \mathrm{g} / \mathrm{g}$ ) were impala lily, butterfly pea,

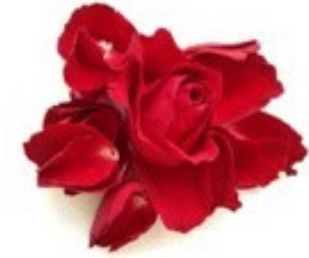

1

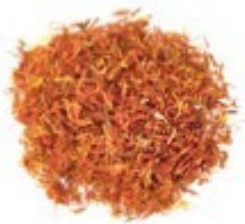

5

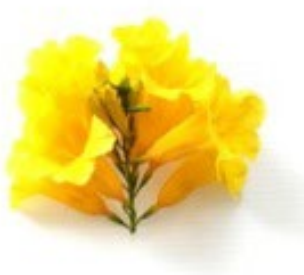

9

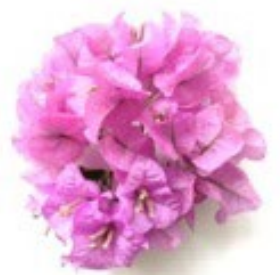

13

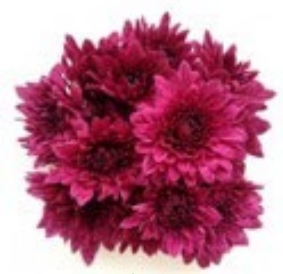

17

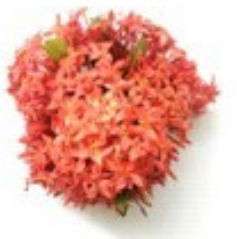

2

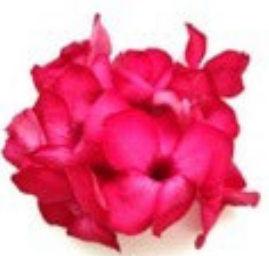

6

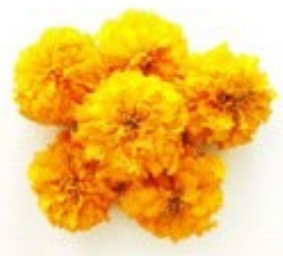

10

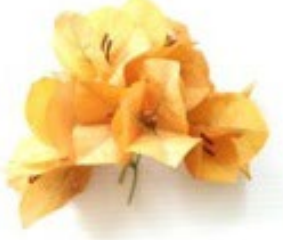

14



18

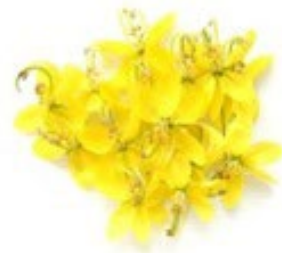

3



7

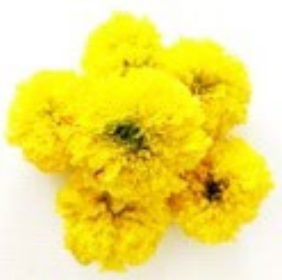

11

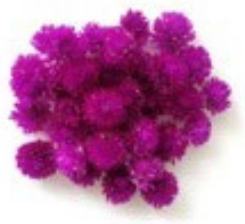

15

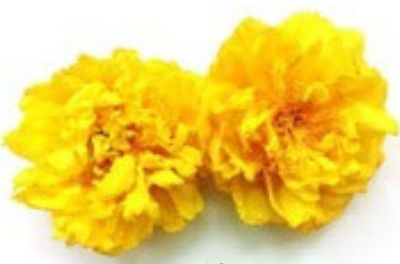

19
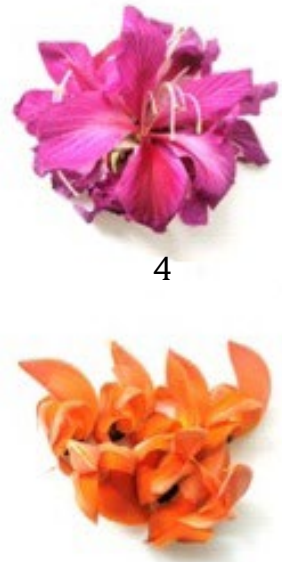

8



12

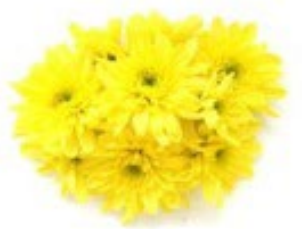

16

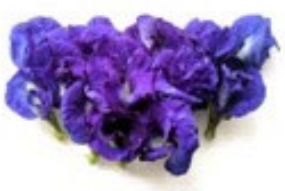

20

Figure 1. Morphology of flower samples ( 1 = rose, $2=$ west Indian jasmine, $3=$ golden shower, $4=$ orchid tree, $5=$ safflower, 6,7 = impala lily, 8 = bastard teak, 9 = trumpetbush, 10-11 marigold, 12-14 = bougaville, $15=$ globe amaranth, $16-$ 18 = chrysanthemum, 19 = yellow silk cotton, and $20=$ butterfly pea) 
magenta chrysanthemum, orchid tree, bastard teak, globe amaranth, safflower, and rose.

The results on antioxidant activities against $\mathrm{DPPH}$ and ABTS radicles were also presented in Table 1 and Figure 2. A great diversity among tested flowers in their antioxidant activities was found. Six tested flowers, including orange marigold, deep yellow chrysanthemum, yellow silk cotton, yellow trumpetbush, yellow marigold, and yellow golden shower had significantly higher antioxidant activities than others $(\mathrm{P}<0.01)$. Their DPPH-antioxidant activities were as $32.34 \pm 2.16$, $29.41 \pm 0.57,28.69 \pm 1.03,28.20 \pm 0.61,29.60 \pm 0.98$, and $20.07 \pm 1.11 \%$, respectively. Likewise, high antioxidant activities against ABTS radicles were also found from the same six tested flowers, which were $50.08 \pm 0.87$, $33.90 \pm 0.81,35.70 \pm 1.79,35.21 \pm 1.26,33.23 \pm 0.55$, and $28.15 \pm 0.15 \%$, respectively. The rest showed some antioxidant activities against DPPH and ABTS radicles, but their antioxidant powers were not as high as those of six flowers. Relationships between total carotenoid content and DPPH and ABTS antioxidant property were analyzed. The significantly positive correlations of total carotenoid content and all antioxidant assay were found at $\mathrm{P}<0.01$ (Table 2 ). The correlation coefficients between total carotenoid content and DPPH and ABTS antioxidant property were $r=0.6924$ and 0.8270 , respectively.

\subsection{Carotenoid Profiles}

The first 6 pigment extracts from flower petals with high total carotenoid content, including orange marigolds, deep yellow chrysanthemum, yellow silk cotton, yellow trumpetbush, yellow marigold and yellow golden shower were subjected to carotenoid profile analysis. Yellow and orange spots were obtained on TLC plates as shown in Figure 3. In order to identify the pigments, JustTLC software, version 4.6.1 was carried out for TLC analysis (Figure 4). Comparing $\mathrm{Rf}$ values and color for spots of pigment extracts with those of standard carotenoids, spot 3 (lane 4), spot 17 (lane 6) and spot 22 (lane 9) were identified as $\beta$-carotene $\left(\mathrm{R}_{\mathrm{f}}=0.882\right)$. Considering spot 25 (lane 5 ) and spot 21 (lane 8 ), they were both identified as lutein and/or zeaxanthin with the $\mathrm{R}_{\mathrm{f}}$ of 0.266 . Nevertheless, spot 23 (lane 4), spot 13, 24, 30 (lane 5), spot 14, 27 (lane 6), spot 19 (lane 7), spot 11 (lane 8), and spot 28, 29 (lane 9) were unknown carotenoids because they showed no coincidence of $\mathrm{R}_{\mathrm{f}}$ value with any carotenoid standards.

Table 1. Total carotenoids content and antioxidant activities

\begin{tabular}{|c|c|c|c|c|c|}
\hline \multicolumn{2}{|c|}{ Sample } & \multirow{2}{*}{$\begin{array}{c}\text { Color of flower } \\
\text { petals }\end{array}$} & \multirow{2}{*}{$\begin{array}{l}\text { Total carotenoids } \\
\frac{\text { content }}{(\mu \mathrm{g} / \text { gram sample })}\end{array}$} & \multicolumn{2}{|c|}{ Radicle inhibition (\%) } \\
\hline Scientific name & Common name & & & DPPH & ABTS \\
\hline Rosa hybrida & rose & red & $5.79 \pm 1.32^{k}$ & $15.68 \pm 0.68^{\mathrm{cd}}$ & $16.36 \pm 0.72^{\mathrm{h}}$ \\
\hline Ixora chinensis Lamk & west Indian jasmine & red & $113.86 \pm 6.68^{g}$ & $9.12 \pm 1.94^{\mathrm{hi}}$ & $13.65 \pm 1.30^{\mathrm{i}}$ \\
\hline Cassia fistula L. & golden shower & yellow & $363.88 \pm 12.74^{\mathrm{d}}$ & $20.07 \pm 1.11^{c}$ & $28.15 \pm 0.15^{d}$ \\
\hline Bauhinia purpurea L. & orchid tree & magenta & $13.05 \pm 1.61^{\mathrm{k}}$ & $11.53 \pm 2.47^{\mathrm{fgh}}$ & $13.20 \pm 1.88^{\mathrm{i}}$ \\
\hline Carthamus tinctorius L. & safflower & red & $24.47 \pm 1.23^{j \mathrm{k}}$ & $13.13 \pm 1.18^{\text {cdef }}$ & $14.29 \pm 0.38^{\mathrm{i}}$ \\
\hline $\begin{array}{l}\text { Adenium obesum (Fosk.) } \\
\text { Roem. and Schult. }\end{array}$ & impala lily & deep magenta & $15.37 \pm 1.18^{\mathrm{k}}$ & $9.16 \pm 1.09^{h i}$ & $15.70 \pm 0.57^{\mathrm{hi}}$ \\
\hline $\begin{array}{l}\text { Adenium obesum (Fosk.) } \\
\text { Roem. and Schult. }\end{array}$ & impala lily & magenta & $75.88 \pm 3.63^{\mathrm{gh}}$ & $10.40 \pm 0.28^{\mathrm{gh}}$ & $16.22 \pm 0.46^{\mathrm{h}}$ \\
\hline Butea monosperma & bastard teak & orange & $20.37 \pm 1.39^{j k}$ & $7.44 \pm 1.74^{\mathrm{i}}$ & $15.83 \pm 0.57^{\mathrm{hi}}$ \\
\hline Tecoma stans & trumpetbush & yellow & $429.46 \pm 28.34^{c}$ & $28.20 \pm 0.61^{b}$ & $35.21 \pm 1.26^{b}$ \\
\hline Tagetes erecta & marigold & orange & $2,209 \cdot 34 \pm 75.58^{a}$ & $32.34 \pm 2.16^{\mathrm{a}}$ & $50.08 \pm 0.87^{a}$ \\
\hline Tagetes erecta & marigold & yellow & $409.85 \pm 34.58^{c}$ & $29.60 \pm 0.98^{b}$ & $33.23 \pm 0.55^{c}$ \\
\hline Bougainvillea spp. & bougaville & magenta & $170.35 \pm 9.02^{\mathrm{f}}$ & $12.22 \pm 0.93^{\mathrm{efg}}$ & $18.10 \pm 0.47^{g}$ \\
\hline Bougainvillea spp. & bougaville & violet & $214.38 \pm 10.35^{\mathrm{e}}$ & $12.22 \pm 0.40 \mathrm{efg}$ & $24.92 \pm 0.62^{e}$ \\
\hline Bougainvillea spp. & bougaville & orange & $199.54 \pm 15.26^{\mathrm{ef}}$ & $14.16 \pm 0.33^{\text {cde }}$ & $25.56 \pm 1.84^{\mathrm{e}}$ \\
\hline Gomphrena globosa L. & globe amaranth & violet & $15.80 \pm 0.84^{\mathrm{jk}}$ & $9.30 \pm 1.51^{\text {hi }}$ & $18.07 \pm 0.57^{\mathrm{g}}$ \\
\hline $\begin{array}{l}\text { Chrysanthemum morifolium } \\
\text { Ramat. }\end{array}$ & chrysanthemum & yellow & $238.18 \pm 31.86^{e}$ & $12.66 \pm 0.05^{\text {defg }}$ & $16.41 \pm 1.01^{\mathrm{h}}$ \\
\hline $\begin{array}{l}\text { Chrysanthemum morifolium } \\
\text { Ramat. }\end{array}$ & chrysanthemum & magenta & $56.56 \pm 2.15^{\mathrm{hij}}$ & $14.51 \pm 4.49^{\text {cde }}$ & $22.65 \pm 0.92^{\mathrm{f}}$ \\
\hline $\begin{array}{l}\text { Chrysanthemum morifolium } \\
\text { Ramat. }\end{array}$ & chrysanthemum & deep yellow & $551.27 \pm 47.72^{\mathrm{b}}$ & $29.41 \pm 0.57^{b}$ & $33.90 \pm 0.81^{c}$ \\
\hline Cochlospermum regium & yellow silk cotton & yellow & $447.42 \pm 27.56^{c}$ & $28.69 \pm 1.03^{b}$ & $35.70 \pm 1.79^{b}$ \\
\hline Clitoria ternatea L. & butterfly pea & dark blue & $62.51 \pm 3.96^{\mathrm{hi}}$ & $11.53 \pm 1.12^{\text {fgh }}$ & $11.32 \pm 0.19^{j}$ \\
\hline
\end{tabular}

Means with different letter within a column of each group are significantly different $(\mathrm{P}<0.01)$ 
2,500 60

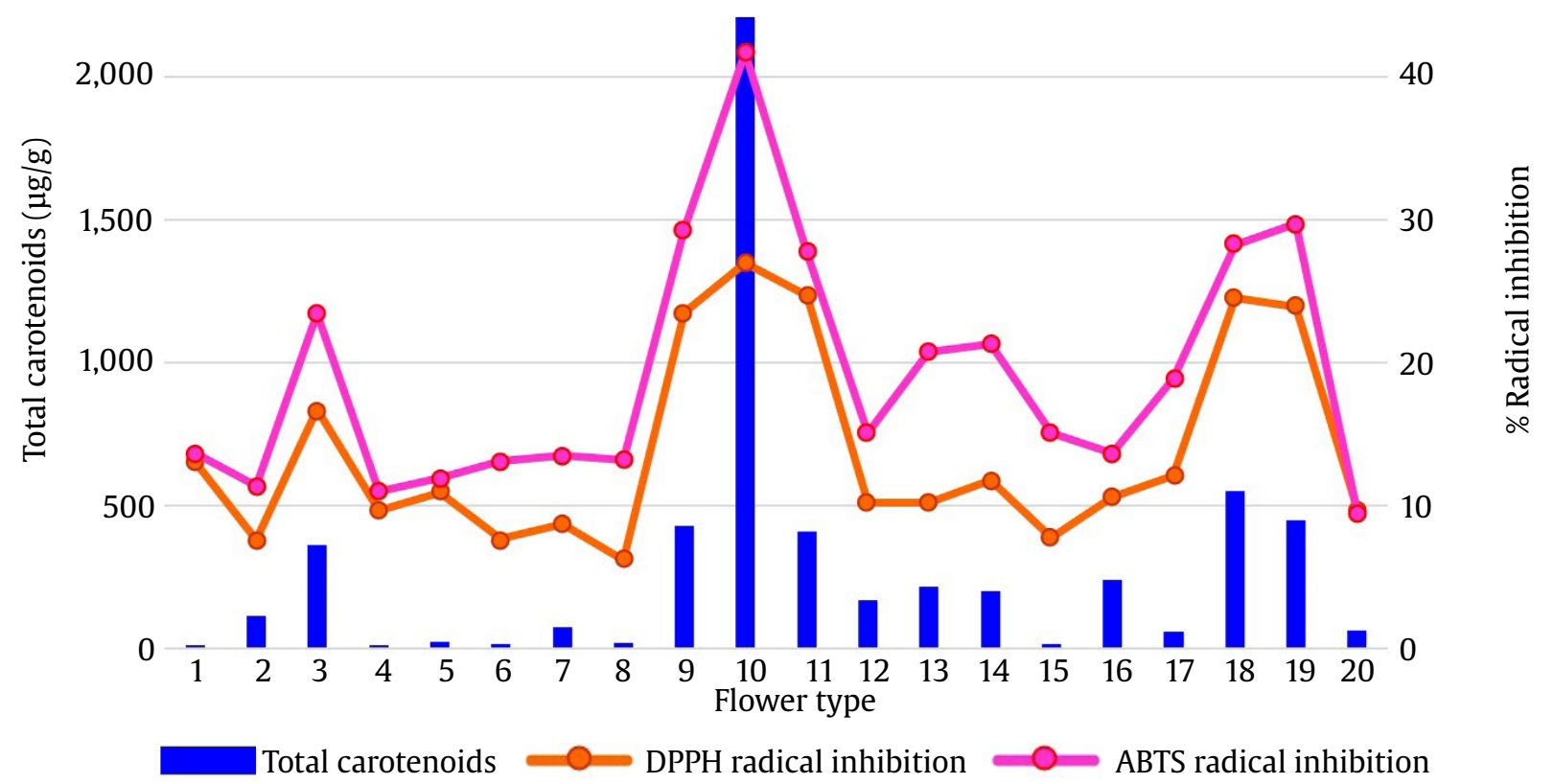

Figure 2. Total carotenoids content and antioxidant activities $(1=$ rose, $2=$ west Indian jasmine, $3=$ golden shower, $4=$ orchid tree, 5 = safflower, 6,7 = impala lily, 8 = bastard teak, 9 = trumpetbush, 10-11 marigold, 12-14 = bougaville, 15 = globe amaranth, $16-18=$ chrysanthemum, 19 = yellow silk cotton, and $20=$ butterfly pea)

Table 2. Correlation of total carotenoid content and antioxidant activities

\begin{tabular}{lcc}
\hline Factor & $\begin{array}{l}\text { Total carotenoid } \\
\text { content }\end{array}$ & $\begin{array}{l}\text { \% DPPH Radical } \\
\text { inhibition }\end{array}$ \\
\hline $\begin{array}{l}\text { \% DPPH radical } \\
\text { inhibition }\end{array}$ & $0.6924^{* *}$ & \\
$\begin{array}{l}\text { \% ABTS radical } \\
\text { inhibition }\end{array}$ & $0.8270^{* *}$ & $0.8731^{* *}$ \\
${ }^{* *}$ means significant correlation $(\mathrm{P}<0.01)$ &
\end{tabular}

\section{Discussion}

The results on total carotenoid contents from flower petals coincided with the observation of following studies. Tanoi et al. (2006) compared carotenoid pigments among 8 commonly grown garden flowers and concluded that the highest number of total carotenoids was found in the family Compositae, especially in marigold. Supporting results was also provided by Tangmo et al. (2019) which showed that yellow silk cotton and golden shower contained higher carotenoid contents in term of $\beta$-carotene $(28.91 \pm 0.43$ and $22.95 \pm 0.20 \mu \mathrm{g} \beta$-carotene/100 g dried weight, respectively). Notably, high total carotenoid content in this study was obtained by flowers with yellowish flower petals. It seemed that the more yellowish flower petals are, the more total carotenoids obtain. Our findings leaded to the proposed idea that color of flower petals relied on the level of carotenoid content. Our proposed idea well agreed with the research conducted by Wang et al. (2018) which compared carotenoid accumulation and investigate its contribution in coloration of Osmanthus fragrans. Their research revealed that difference in flower coloration of $O$. fragrans were mainly attributed by the level of carotenoids and color became more deeper with carotenoid accumulation. Not only the level of carotenoid accumulation in flower petals is influent on flower petal color, but the type of carotenoid compound is also a key factor. According to the studies of Moehs et al. (2001) and Ohmiya (2011), the xanthophylls which impart pale yellow, deep yellow to orange color to flower petals were lutein, $\beta$-cryptoxanthin and zeaxanthin as well as the carotenes such as $\beta$-carotene and lycopene were responsible for deep yellow to orange color to flower petals. Though, the petals of some flowers have modified carotenoid biosynthesis pathways to produce specific carotenoid compositions. For example, the petals of Adonis aestivalis and A. annua accumulate large amount of astaxanthin, resulting in their distinctive blood-red color (Cunningham and Gantt 2005). In addition, the study from Grotewold (2006) explained that there were 3 major classes of pigments that could attribute to flower coloration. One was carotenoids and another were flavonoid and betalain. Therefore, in term of flowers with low total carotenoid contents in this study, the main pigments accumulated in petals could be anthocyanin and betalain. This idea was in 


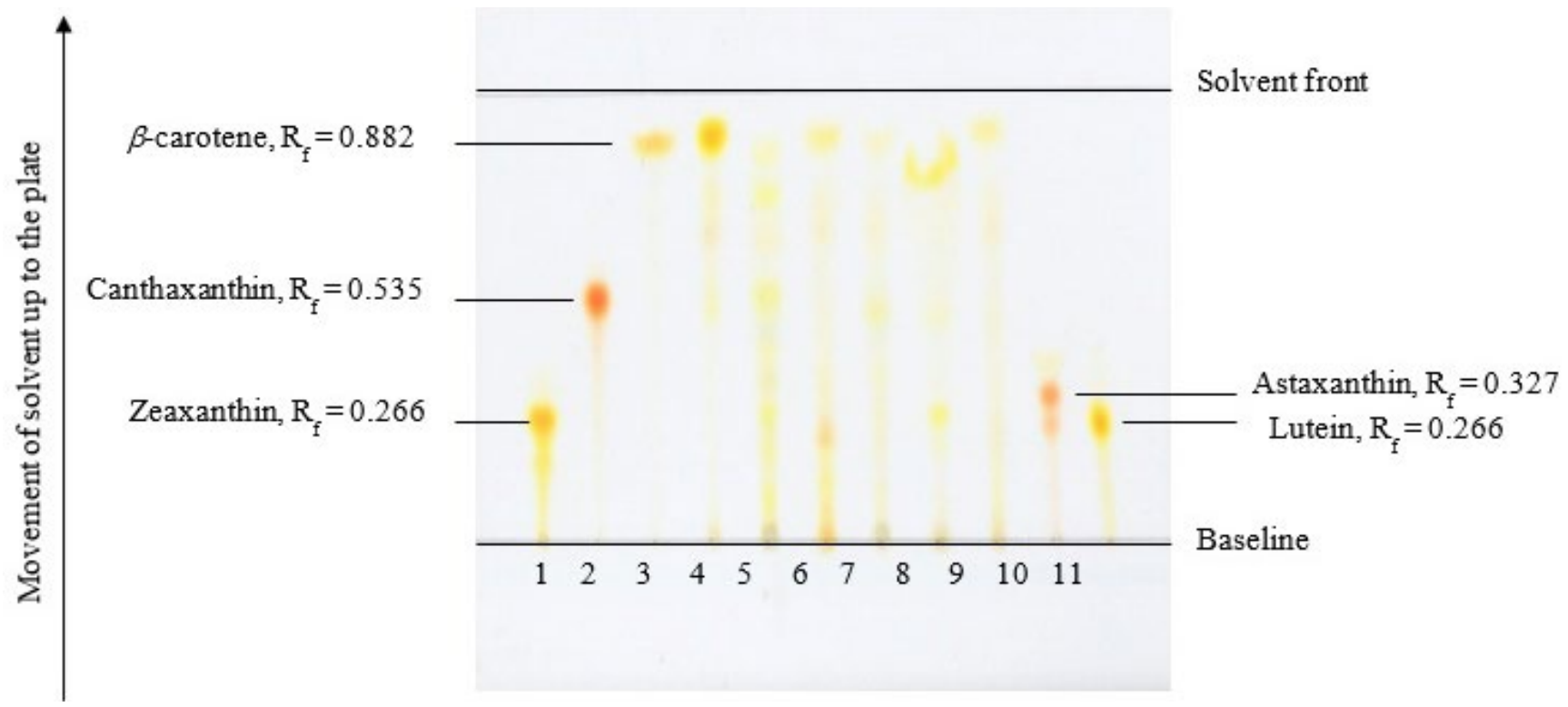

Figure 3. Silica TLC plate on which carotenoids standards and flower petals extracts $(1=$ zeaxanthin, $2=$ canthaxanthin, $3=$ $\beta$-carotene, 4 = orange marigold, 5 = deep yellow chrysanthemum, $6=$ yellow silk cotton, $7=$ yellow trumpetbush, 8 = yellow marigold, 9 = yellow golden shower, 10 = astaxanthin, $11=$ lutein)


Figure 4. Silica TLC plate on which carotenoids standards and flower petals extracts, analyzed by Just TLC version 4.6.1. $(1=$ zeaxanthin, 2 = canthaxanthin, $3=\beta$-carotene, 4 = orange marigold, $5=$ deep yellow chrysanthemum, $6=$ yellow silk cotton, 7 = yellow trumpetbush, $8=$ yellow marigold, $9=$ yellow golden shower, $10=$ astaxanthin, $11=$ lutein) 
an agreement with several studies, which explained that anthocyanin was abundant in petals of rose, west Indian jasmine, shoe flower (Hibiscus rosa-sinensis) and butterfly pea (Tantituvanont et al. 2008; Vankar and Srivastava 2010).

The results of antioxidant activities showed that orange marigold, deep yellow chrysanthemum, yellow silk cotton, yellow trumpetbush, yellow marigold and yellow golden shower were a good source of antioxidants. This finding shared similarity to several studies which previously reported that marigold especially Optiva Orange and Rodeo Gold, yellow silk cotton and golden shower showed high antioxidant activities (Ingkasupart et al. 2015; Yaemkong et al. 2020). The results implied that total carotenoid contents in flower petals was responsible for their antioxidant activities which was in an agreement to the finding from Benvenuti et al. (2016). Their work explained that color of flowers as a result of pigment accumulation in petals not only contribute to increase their appeal towards customers, but also the antioxidant activity. The relationships between total carotenoid content and antioxidant activities were also examined in this study and the positive corrections between total carotenoid content and antioxidant activities against DPPH and ABTS radicles were found. Our finding was supported by the studies from Yaemkong et al. (2020) and Ingkasupart et al. (2015), which also reported a positive correlation between antioxidant effects and carotenoids. However, the correlation between total carotenoid content and DPPH antioxidant activity in this study was lower than that of total carotenoid content and ABTS antioxidant activity. This might be a result of a structural diversity of antioxidants. Different types of antioxidants might act differently to reduce free radicals, leading to different antioxidant efficiency and correlation (Müller et al. 2011). Therefore, it suggested that more than one antioxidant method would rather be used for antioxidant examination.

Carotenoid profile analysis by TLC clearly showed that carotenoid profile of each flower petal was distinct. The $\beta$-carotene which is a provitamin A was the dominant pigment in orange marigold, yellow silk cotton and yellow golden shower while lutein and/or zeaxanthin was dominant in deep yellow chrysanthemum and yellow marigold. Our results correlated with the study from Kishimoto et al. (2005); Ohmiya (2011); Ingkasupart et al. (2015) whose result showed that lutein was the main pigment in yellow chrysanthemum and yellow marigold. Although, in this study lutein and zeaxanthin could not be differentiated because of the same $R_{\mathrm{f}}$ value, to the best of our knowledge, our study firstly identified the carotenoid compositions in yellow silk cotton, yellow golden shower and yellow trumpetbush. Therefore, this new information would be useful for considering these flowers as a new and $\operatorname{good} \beta$-carotene source. In addition, the method used for extraction and identification of carotenoids in this study was simple, inexpensive and less time consuming, which could be applied for screening carotenoid compositions from many samples in a single run without using sophisticated equipment.

It could be concluded that flower petals possessed different total carotenoid contents and antioxidant activities against DPPH and ABTS. Orange marigold, deep yellow chrysanthemum, yellow silk cotton, yellow trumpetbush, yellow marigold and yellow golden shower provided high total carotenoid content and antioxidant activities. Considering the carotenoid profiles, orange marigolds, yellow silk cotton and yellow golden shower were a good source of $\beta$-carotene, while deep yellow chrysanthemum and yellow marigold were a good source of lutein and/or zeaxanthin. Therefor these flower petals would be useful for using as natural carotenoid source as well as beneficial to provide antioxidants for food and pharmaceutical industry.

\section{Conflict of Interest}

The authors declare no conflict of interest.

\section{Acknowledgements}

This research is financially supported by Thailand Science Research and Innovation, fiscal year 2021 and technically supported by Kalasin University. The authors would like to thank Mr. Wirat Sripor, Mr. Kritsada Heman and Mr. Phongphat Phalaho for providing data to this work. Sila Yimsiri is also much appreciated. Without their supports, this work could not have been done.

\section{References}

Brand-Williams, W., Cuvelier, M.E., Berset, C., 1995. Use of a free radical method to evaluate antioxidant activity. Lebensmittel. Wissenschaft. und-Technolgie. 28, 2530. https://doi.org/10.1016/S0023-6438(95)80008-5

Britton, G., Liaaen-Jensen, S., Pfander, H., 1995a. Carotenoids Vol. 1A. Isolation and analysis, BirkhäuserVerlag, Basel. https://doi.org/10.1007/978-3-0348-9323-7

Britton, G., Liaaen-Jensen, S., Pfander, H., 1995b. Carotenoids Vol.1B.Spectroscopy, BirkhäuserVerlag, Basel. https:// doi.org/10.1007/978-3-0348-9323-7

Britton, G., Liaaen-Jensen, S., Pfander, H., 2004. Carotenoids Handbook, Birkhäuser, Basel. https://doi. org/10.1007/978-3-0348-7836-4

Britton, G., Liaaen-Jensen, S., Pfander, H., 2017. Carotenoids: A Colourful History, Carote Nature, Bern.

Benvenuti, S., Bortolotti, E., Maggini, R., 2016. Antioxidant power, anthocyanin content and organoleptic performance of edible flowers. Sci. Hortic. 199, 170177. https://doi.org/10.1016/j.scienta.2015.12.052 
Cunningham, F.X., Gantt, E., 2005. A study in scarlet: enzymes of ketocarotenoid biosynthesis in the flowers of Adonis aestivalis. Plant J. 41, 478-492. https://doi. org/10.1111/j.1365-313X.2004.02309.x

Englmaierová, M., Bubancová, I.,Skřrivan, M., 2014. Carotenoids and egg quality. Acta fytotechn. zootechn. 17, 55-57. https://doi.org/10.15414/afz.2014.17.02.55-57

Grotewold, E., 2006. The genetics and biochemistry of floral pigments. Ann. Rev. Plant Biol. 57, 761-780. https:// doi.org/10.1146/annurev.arplant.57.032905.105248

Ingkasupart, P., Manochai, B., Song, W.T., Hong, J.H., 2015. Antioxidant activities and lutein content of 11 marigold cultivars (Tagetes spp.) grown in Thailand. Food Sci. Technol. 35, 380-385. https://doi.org/10.1590/1678457X.6663

Karadas, F., Grammenidis, E., Surai, P.F., Acamovic, T., Sparks, C., 2006. Effects of carotenoids from Lucerne, marigold and tomato on egg yolk pigmentation and carotenoid composition. B. Poult. Sci. 47, 561-566. https://doi. org/10.1080/00071660600962976

Kishimoto, S., Maoka, T., Sumitomo, K., Ohmiya, A., 2005. Analysis of carotenoid composition in petals of calendula (Calendula officinalis L.). Biosci. Biotechnol. Biochem. 69, 2122-2128. https://doi.org/10.1271/ bbb.69.2122

Kljak. K., Carović-Stanko, K., Kos, I., Janječić, Z., Kiš, G., Duvnjak, M., Safner, T., Bedeković, D., 2021. Plant carotenoids as pigments sources in laying hen diets: effect on yolk color, carotenoid content, oxidative stability and sensory properties of eggs. Foods. 10, 721. https://doi.org/10.3390/foods10040721

Maoka, T., 2020.Carotenoids as natural functional pigments. J. Nat. Med. 74, 1-16. https://doi.org/10.1007/s11418019-01364-X

Moehs, C.P., Tian, L., Osteryoung, K.W., DellaPenna, D., 2001. Analysis of carotenoid biosynthetic gene expression during marigold petal development. Plant Mol. Bio. 45, 281-293. https://doi.org/10.1023/A:1006417009203

Müller, L., Fröhlich, K., Böhm, V. 2011. Comparative antioxidant activities of carotenoids measured by ferric reducing antioxidant power (FRAP), ABTS bleaching assay ( $\alpha$ TEAC), DPPH assay and peroxyl radical scavenging assay. Food Chem. 129, 139-148. https://doi.org/10.1016/j.foodchem.2011.04.045

Ohmiya, A., 2011. Diversity of carotenoid composition in flower petals. Jpn. Agric. Res. Q. 45, 163-171. https:// doi.org/10.6090/jarq.45.163
Panaite, T.D., Nour, V., Saracila, M., Turcu, R.P., Untea, A.E., Vlaicu, P.A. 2021. Effects of linseed meal and carotenoids from different sources on egg characteristics, yolk fatty acid and carotenoid profile and lipid peroxidation. Foods. 10, 1246. https://doi. org/10.3390/foods10061246.

Re, R., Pellegrini, N., Proteggente, A., Pannala, A., Yang, M., Rice-Evans, C., 1999. Antioxidant activity applying an improved ABTS radical cation decolorization assay. Free Radic. Biol. Med. 26, 1231-1237. https://doi. org/10.1016/S0891-5849(98)00315-3

Skřivan, M., Englmaierová, M., Skřivanová, E., Bubancová, I. 2015. Increase in lutein and zeaxanthin content in the eggs of hens fed marigold flower extract. Czech J. Anim. Sci. 17, 55-57.

Tantituvanont, A., Werawatganone, P., Jianchaisri, P., Manopakdee, K., 2008. Preparation and stability of butterfly pea color extract loaded in microparticles prepared by spray drying. Thai J. Pharm. Sci. 32, 59-69.

Tangmo, S., Howhan, S., Gothrom, P., Tuan, N.N., Sonmanee, S., Yaemkong, S., 2019. Analyses of bioactive ingredients and pigments from some edible flowers for poultry diets. Naresuan Agriculture Journal. 16, 57-64.

Tanoi, J., Rakariyatham, N., Deming, R.L., 2006. Determination of major carotenoid constituents in petal extracts of eight selected flowering plants in the north of Thailand. Chiang Mai J. Sci. 33, 327-334.

Vankar, P., Srivastava, J., 2010. Evaluation of anthocyanin content in red and blue flowers. International Journal of Food Engineering. 6, 1-11. https://doi. org/10.2202/1556-3758.1907

Wang, Y., Zhang, C., Dond, B., Fu, J., Hu, S., Zhao, H., 2018. Carotenoid accumulation and its contribution to flower coloration of Osmanthus fragrans. Front. Plant Sci. 9: 1499. https://doi.org/10.3389/fpls.2018.01499

Yaemkong, S., Tangmo, S., Howhan, S., Kotom, P., Jaipong, P., Ngoc, T.N., Sonmanee, S., 2020. Chemical composition, antioxidant activitiesm flavonoid, carotenoid and total phenolic contents of some flowers. Khon Kaen Agr. J. 48, 1011-1015.

Zeb, A., Murkovic, M., 2010. Thin-layer chromatographic analysis of carotenoids in plant and animal samples. J. Planar. Chromat. 23, 94-103. https://doi.org/10.1556/ JPC.23.2010.2.1 